\title{
INTEGRATED MARKETING COMMUNICATIONS. THE COCA-COLA SPAIN IMC MODEL
}

\section{COMUNICACIONES INTEGRADAS DE MARKETING. EL MODELO DE CIM DE COCA-COLA ESPAÑA}

Francisco Suay (Universidad CEU Cardenal Herrera) ${ }^{1}$

\section{Resumen:}

En el desarrollo de las Comunicaciones Integradas de Marketing (CIM), en estos más de 30 años de evolución, se han desarrollado múltiples estudios para comprender el concepto, sus dimensiones, así como la implicación para consumidores y empresas.

En este artículo revisamos el concepto del CIM desde una perspectiva teórica y profundizamos en cada uno de sus componentes. Posteriormente, para completar la revisión teórica, analizamos las dimensiones que componen el CIM.

Uno de los aspectos menos tratados por la literatura ha sido la implicación de los consumidores y cómo las empresas han adaptado sus estructuras de marketing a este nuevo concepto. En este trabajo, se analiza la estructura de la compañía Coca-Cola en España y como ha modificado su forma de trabajar para adecuarse a un modelo de CIM donde el propio responsable de marketing tiene el cargo que se ocupa de la CIM. El departamento de marketing ha cambiado su estructura, metodología y la forma de integrarse internamente y con los proveedores de marketing para adecuarse a una estrategia totalmente basada en los principios de la CIM.

Palabras Clave: Comunicación, Estructura, Comunicaciones Integradas de Marketing, IMC, Marketing, Coke.

Códigos JEL: M31.

\section{Abstract:}

In the development of the Integrated Marketing Communications (IMC), in these more than 30 years of evolution, multiple studies have been developed to understand the concept, its dimensions as well as the implication for consumers and companies.

In this article we review the concept of the IMC taking a theoretical perspective and delve into each of its components. To complete the theoretical review, we analyze the dimensions that make up the IMC.

One of the aspects that has received poor attention by the literature has been the involvement of consumers and how companies have adapted their marketing structures to this new concept. In this paper we look into the structure of the Coca-Cola company in Spain and how it has modified its working patterns to adapt to an IMC model, where the marketing manager himself is in charge of the IMC management. The marketing department has changed the structure, the methodology and the way of integrating internally and with the marketing providers to adapt to a strategy totally based on the IMC principles.

Keywords: Communications, Structure, Integrated Marketing Communications, IMC, Marketing, Coke.

JEL Code: M31.

\footnotetext{
${ }^{1}$ francisco.suay@uchceu.es, Universidad CEU Cardenal Herrera.

Recibido: 5 de noviembre de 2020. Aceptado: 23 de noviembre de 2020.
} 


\section{INTRODUCTION}

For years Northwestern University has offered very differentiated and separate degree programs in corporate public relations, advertising and direct marketing and then the three programs were merged into one: Integrated Marketing Communications (IMC). In 1989, the new Dean of the school of journalism at Northwestern University created a faculty study group to propose a long-term strategy for a curriculum in the advertising division. With the contribution of students and professionals emphasized strongly the idea of integration and the need for a new way of thinking leading to the new program of Integrated Marketing Communications, with five quarters of duration (Caywood et al., 1991).

The term IMC, Integrated Marketing Communications, takes body in 1989, when the American Association of Advertising Agencies (AAAA), which was founded in 1917, published its first definition in order to use it in a national study in cooperation with the Association of National Advertisers (ANA) of in United States and Don E. Schultz at Northwestern University (Caywood et al., 1991). The first conceptualization of IMC reads as follows:

"A concept of the planning of marketing communications that recognizes the added value of a comprehensive plan that evaluates the strategic role of a variety of disciplines of communication, as for example, advertising in general, direct response, sales promotion and public relations, and combines these disciplines to provide clarity, consistency and maximum impact communications".

As Porcu, del Barrio-Garcia and Kitchen (2012) remarks, for more than two decades, academics and practitioners have debated about the concept of Integrated Marketing Communications without reaching an agreement on what is and what benefits offers, so the paradigm is still unclear from the definition to the limits of application, as it is relatively new. In this regard, Kliatchko (2008) suggested that "the IMC still requires research work on issues of definition at this time and to work towards a consensus on the fundamental principles of the IMC is a step towards the consolidation of a common framework for the understanding and practice of the concept".

\section{THE CONCEPT OF INTEGRATED MARKETING COMMUNICATION}

Don E. Schultz formalized the concept of IMC in United States with his seminal works in special issues published in the Journal of Business Research and the Journal of Marketing Communications in 1996. However, most of the texts and books about marketing communications and marketing published during the 1990s, adopted some kind of approach to integrated communication (Schultz and Kitchen, 1997).

Kliatchko (2008) reviewed in his paper the topics that have dominated research studies from its inception to 2006 highlighting the role of the "definitions, perceptions, understanding and theoretical foundations surrounding the IMC concept".

Using the structure proposed by Porcu, del Barrio-Garcia and Kitchen in 2012, the definitions of IMC can be classified into 3 categories:

- The "inside-out" approach.

- The "outside-in" approach.

- $\quad$ The cross-functional strategic approach.

This first approach only focuses on the firm point of view and the efforts to communicate "one voice", without adopting a consumer orientation and where the integration only deals with the marketing communications tools and messages. This approach reflects the early stages of 
Integrated Marketing Communications with the aforementioned conceptualization of the American Association of Advertising Agencies and the definition proposed by Duncan and Everett, who considered that IMC is:

"The strategic coordination of messages and media used by an organization to influence your perceived brand value" (Duncan and Everett, 1993).

Kotler (2000) also centred his definition on how the firms integrates and coordinates all the communications identifying the IMC as:

"A concept under which a company carefully integrates and coordinates their multiple communication channels to provide a clear, coherent and compelling message about the organization and its products" (Kotler, 2000).

In the second category of definitions reflecting "the outside in" approach, the origin is what consumers want and requires a deep understanding of clients, customers and prospects, as Pickton and Broderick (2005) identify as "all agents". Perhaps one of the most known definitions of Integrated Marketing Communications was proposed by Don E. Schultz in the earlies 90's highlighting customers and prospects, clients and potential clients and selected audience as the way to reach a completed integration.

"Integrated Marketing Communications is the process of development and implementation of various programs of persuasive communication with customers and prospects through time. IMC aims to influence or directly affect the behavior of the selected audience. In summary the IMC process begins with the client or potential client and then returns to determine and define the forms and methods of persuasive communication programs should be developed through which" (Schultz, 1993).

Following a review of the main definitions and approaches to the concept of Integrated Marketing Communications, Kliatchko (2005) proposes

"IMC is the concept and process of strategically managing audience-focused, channelcentered, and results-driven brand communication programs over time” (Kliatchko, 2005).

This definition is based on four pillars:

- concept and process,

- requires knowledge and skills of strategic thinking and business management,

- $\quad$ hinged on three elements: audience-focused, channel-centered, and results-driven.

- Involves and expanded view of brand communications.

This author modifies his definition with a new one focused on the audience-driven in 2008 that we detail as part of the cross-functional strategic approach.

The third approach refers to the strategic approach and, in this regard, Porcu, del BarrioGarcia and Kitchen (2012) considered that the key points are the consumer analysis and segmentation, to restructuring the organization in a circular process that implies all departments and external agencies.

One of the most important definitions that emphasizes the strategic aspect of IMC is the one elaborated by Schultz and Kitchen in 2000 and also published in 2004 in "IMC the next generation" by Schultz and Schultz (2004), which will be completing the previous contributions and involve all levels of the company:

"is a strategic management process to plan, execute and evaluate coordinated brand communication programs measurable and persuasive continuously with consumers, customers, and other targets, both internal external, relevant how for the company". (Schultz and Kitchen, 2000). 
It is not only the coordination of communication tools, but rather the development of a strategic business process. Similarly, Duncan and Moriarty (1998) proposed "A Communication-Based Marketing Model for Managing Relationships", where the authors adopted an integration perspective and develop "a communication-based model of relationship marketing [that] underlines the importance of managing all brand communication as they collectively create, maintain, or weaken the profitable stakeholder relationship that drive brand value" (Duncan and Moriarty, 1998).

As we mentioned earlier, the definition of Kliatchko (2005) made clear the strategic process behind IMC and in 2008 he revised his IMC definition suggesting that:

"IMC is an audience-driven business process of strategically managing stakeholders, content, channels, and results of brand communication programs” (Kliatchko, 2008).

This new definition explicitly includes the terms "content" and "business process", which was introduced by Schultz and Schultz. (2004). Business process and strategic management process involve all functions of the organization and not only marketing.

Adding this idea that Integrated Marketing Communications involves more than just integration of marketing communications. In this regard, Pickton and Broderick (2005) detail the analysis, planning, implementation and control, defining IMC as:

"a process that involves the direction and organization of all the agents in the analysis, planning, implementation and control of all contacts, media, messages and promotional tools of marketing communications focused on public goals selected, so that they result in greater economy, efficiency, effectiveness, improvement and coherence of efforts of communication from the company for the achievement of the objectives of certain products and corporate marketing communication" (Pickton and Broderick 2005).

Martínez (2006) considers that this definition highlights the major features of the integrated communication strategy: it identifies the goals of marketing communication with other organizational objectives; it is a planned process; it reaches not only consumers but all the publics; it includes all corporate marketing and product/brand communication efforts as all brands or corporate messages must be based on a consistent and common strategy.

While IMC is a term in continuous evolution, as evidenced by the multiple definitions that have arisen in different areas, we can see important advances in which various authors agree, from conceptualization as a simple coordination of communication tools to a much more strategic conceptualization. All these theoretical contributions on the Integrated Marketing Communications concept endorse that we are on the right track in terms of attracting and generating an informed and intellectual discourse among researchers interested in this practice (Madhavaram et al., 2005).

A relevant definition of IMC is provided by Šerić, Gil-Saura, and Ozretić-Došen, (2015), who identify the basic principles to develop the following definition:

"The Integrated Marketing Communication (IMC) is a tactical and strategic consumercentric business process, boosted by advances in Information and Communication Technology (ICT) which, on the basis of information obtained from customers databases, delivers a clear and consistent message through the coordination and synergies of different communications tools and channels, in order to nourish long-lasting profitable relationships with customers and other stakeholders and create and maintain brand equity.” (Šerić, Gil-Saura, and Ozretić-Došen, 2015).

They reviewed in detail the definitions of IMC and highlighted these basic principles:

- It is a tactical and strategic process. 
- It requires a coordination and synergy of different communications tools and channels.

- $\quad$ Clarity and consistence of message.

- Communications centered on data base management.

- Customer-centric communication.

- A component of relationship approach.

- A component of brand equity strategy.

As a summary, Table 1 includes a review of most important definitions of IMC.

Finally, the definition given by Porcu, del Barrio-Garcia and Kitchen (2012) serves as an introduction of the next section where a list of dimensions of IMC is proposed. According to Porcu et al. (2012) IMC is:

"the interactive and systemic process of cross-functional planning and optimization of messages to stakeholders with the aim of communicating with coherence and transparency to achieve synergies and encourage profitable relationships in the short, medium and long-term” (Porcu et al., 2012).

More recently, this definition was refined by Porcu, del Barrio-Garcia and Kitchen (2017), who conceptualized IMC as:

"The stakeholder-centred interactive process of cross-functional planning and alignment of organisational, analytical and communication processes that allows for the possibility of continuous dialogue by conveying consistent and transparent messages via all media to foster long-term profitable relationships that create value" (Porcu et al., 2017).

\begin{tabular}{|l|l|l|}
\hline \multicolumn{3}{|c|}{ TABLE 1: MAIN DEFINITIONS OF IMC } \\
\hline YEAR & AUTHORS & CONCEPT \\
\hline 1989 & $\begin{array}{l}\text { American } \\
\text { Association } \\
\text { of } \\
\text { Advertising } \\
\text { Agencies } \\
\text { (AAAA) }\end{array}$ & $\begin{array}{l}\text { A concept of marketing communications planning that } \\
\text { recognizes the added value in a program that integrates a variety } \\
\text { of strategic disciplines, e.g. general advertising, direct response, } \\
\text { sales promotion and public relations - and combines these } \\
\text { disciplines to provide clarity, consistency, and maximum } \\
\text { impact }\end{array}$ \\
\hline 1993 & $\begin{array}{l}\text { Duncan } \\
\text { and Everett }\end{array}$ & $\begin{array}{l}\text { Strategic coordination of messages and media used by an } \\
\text { organization to influence your perceived brand value }\end{array}$ \\
\hline 1993 & $\begin{array}{l}\text { Schultz } \\
\text { The process of development and implementation of various } \\
\text { programs of persuasive communication with customers and } \\
\text { prospects through time. IMC aims to influence or directly affect } \\
\text { the behavior of the selected audience. In summary the IMC } \\
\text { process begins with the client or potential client and then returns } \\
\text { to determine and define the forms and methods of persuasive } \\
\text { communication programs should be developed through which }\end{array}$ \\
\hline 1998 & $\begin{array}{l}\text { Duncan } \\
\text { and } \\
\text { Moriarty }\end{array}$ & $\begin{array}{l}\text { A communication-based model of relationship marketing } \\
\text { underlines the importance of managing all brand } \\
\text { communication as they collectively create, maintain, or weaken } \\
\text { the profitable stakeholder relationship that drive brand value }\end{array}$ \\
\hline
\end{tabular}




\begin{tabular}{|c|c|c|}
\hline 2000 & Kotler & $\begin{array}{l}\text { The concept under which a company carefully integrates and } \\
\text { coordinates its many communication channels to deliver a clear, } \\
\text { consistent and compelling message about the organization and } \\
\text { its products. }\end{array}$ \\
\hline 2000 & $\begin{array}{l}\text { Schultz and } \\
\text { Kitchen }\end{array}$ & $\begin{array}{l}\text { A strategic business process used to plan, develop, execute and } \\
\text { evaluate coordinated, measurable, persuasive brand } \\
\text { communication programs over time with consumers, } \\
\text { customers, prospects and other targeted relevant external and } \\
\text { internal audiences }\end{array}$ \\
\hline 2002 & Duncan & $\begin{array}{l}\text { A cross-functional process for creating and nourishing } \\
\text { profitable relationships with customers and other stakeholders } \\
\text { by strategically controlling or influencing all messages sent to } \\
\text { the groups and encouraging data-driven purposeful dialogue } \\
\text { with them }\end{array}$ \\
\hline 2005 & Kliatchko & $\begin{array}{l}\text { A concept and process of strategically managing audience- } \\
\text { focused, channel-centred and results-driven brand } \\
\text { communication programs over time. }\end{array}$ \\
\hline 2005 & $\begin{array}{l}\text { Pickton and } \\
\text { Broderick }\end{array}$ & $\begin{array}{l}\text { It is a process that involves the direction and organization of all } \\
\text { the agents in the analysis, planning, implementation and control } \\
\text { of all contacts, media, messages and promotional tools of } \\
\text { marketing communications focused on public goals selected, so } \\
\text { that they result in greater economy, efficiency, effectiveness, } \\
\text { improvement and coherence of efforts of communication from } \\
\text { the company for the achievement of the objectives of certain } \\
\text { products and corporate marketing communication }\end{array}$ \\
\hline 2008 & Kliatchko & $\begin{array}{l}\text { It is an audience-driven business process of strategically } \\
\text { managing stakeholders, content, channels, and results of brand } \\
\text { communication programs }\end{array}$ \\
\hline 2012 & $\begin{array}{l}\text { Porcu, del } \\
\text { Barrio- } \\
\text { Garcia and } \\
\text { Kitchen }\end{array}$ & $\begin{array}{l}\text { The interactive and systemic process of cross-functional } \\
\text { planning and optimization of messages to stakeholders with the } \\
\text { aim of communicating with coherence and transparency to } \\
\text { achieve synergies and encourage profitable relationships in the } \\
\text { short, medium and long-term }\end{array}$ \\
\hline 2015 & $\begin{array}{l}\text { Seric and } \\
\text { Gil }\end{array}$ & $\begin{array}{l}\text { The Integrated Marketing Communication (IMC) is a tactical } \\
\text { and strategic consumer-centric business process, boosted by } \\
\text { advances in Information and Communication Technology } \\
\text { (ICT) which, on the basis of information obtained from } \\
\text { customers databases, delivers a clear and consistent message } \\
\text { through the coordination and synergies of different } \\
\text { communications tools and channels, in order to nourish long- } \\
\text { lasting profitable relationships with customers and other } \\
\text { stakeholders and create and maintain brand equity }\end{array}$ \\
\hline
\end{tabular}

Source: Own elaboration. 


\section{DIMENSIONS OF INTEGRATED MARKETING COMMUNICATIONS}

Continuing with the last definition, Porcu, del Barrio-Garcia and Kitchen (2012) differentiate the multidimensional nature of the IMC highlighting 4 dimensions:

- One voice: that represents the core of integration, since it implies the clear delivery of consistent messages across all marketing communications tools.

- Interactivity: IMC intends to establish a permanent dialogue between the organization and its stakeholders, including not only customers, but to all interested publics.

- The cross-functional plan: in traditional marketing communications the starting point is the marketing mix, while, according to this new paradigm, the reference point is the organization as a whole. Integration is a competitive advantage that is able to optimize the relationship between messages, channels and receptors, not only to coordinate the different elements of the marketing mix.

- Long-term profitable relationships: as IMC must be deeply strategic, it must point to the achievement of long-term goals (Porcu et al., 2012)

The above described four dimensions of the IMC assume an integration that affect all variables and aspects to highlight the multidimensionality of the concept.

To reach the dimensions proposed by Porcu, del Barrio-Garcia and Kitchen (2012) we can carry out a review of the most relevant proposals in this regard, starting with that suggested by Nowak and Phelps (1994), based on a literature review, proposing three main themes to analyse:

- a single voice;

- the integration;

- $\quad$ and coordination of marketing communications.

The single voice of marketing suggests that there must be a clear, consistent message and it must be kept in all the communications tools to create a unique positioning or a brand identity. They pointed out that sales promotion, direct marketing, brand advertising, and public relations must be unified under the theme of the voice. Integrated communications perspective holds that in a communication campaign for sales, the tools used for the creation of an image (for example, image ads) and the tools used to influence the actions of consumers (for example, direct response tools how promotions of sale) must be integrated. Finally, the coordination of communications emphasizes measures to implement better coordination among the various tools of communication and channel.

Another view of the multidimensionality of the Integrated Marketing Communication is that companies that develop this strategy should:

- $\quad$ identify several groups of customers differentiated for direct marketing;

- $\quad$ and, therefore, a well-coordinated marketing communications campaign generates synergies, while it generates different responses of behavior depending on the groups of customers that are focused on (Nowak and Phelps, 1994).

Cathey and Schumann (1996), on the basis of a thorough review of the literature, identified three important aspects of the IMC:

- the integration of messages and media;

- $\quad$ audience targeting;

- $\quad$ and impact assessment. 
They emphasized the importance of coordinating messages and media to create more positive communications towards consumers who are at different stages in the process of purchase.

One of the most important and cited articles was a study developed by Phelps and Johnson (1996, which identified five factors that underline the construction of IMC:

- a single voice already treated by most of the authors,

- coordinated marketing communications,

- the use of direct marketing,

- response to specific objectives of such communications,

- and increasing the responsibility of the directors of marketing that grows with the use of the IMC.

The more commonly used measurement scale is that proposed by Duncan and Moriarty (1997), who proposes five dimensions of the Integrated Marketing Communications:

- Interactivity;

- Organizational infrastructure;

- $\quad$ Strategic consistency;

- And planning and evaluation.

Low (2000), in a study of US companies, proposed 3 dimensions to evaluate the dimensions of implementation of IMC:

- Integration;

- Strategic consistency;

- $\quad$ and consistency of the message.

Adopting the insights povided by Duncan and Moriarty, Reid (2005) proposed a modified version, gathering the last three dimensions into one, called "cross-functional strategic planning” and suggesting the following IMC dimensions:

- Interactivity;

- Marketing mission;

- Cross-functional strategic planning.

Lee and Park (2007) provided a more specific definition based on the coordination of marketing communications, as it is seen as a more practical approach. In their study, they develop and validate one of the most widely used measurement scales applying rigorous procedures.

They established four main dimensions of IMC:

- Unified communications for consistency of message and image,

- Different communication tools for multiple groups of consumers,

- Communications focused on databases to obtain tangible results,

- $\quad$ Promote the communication relationships with existing customers.

Figure 1 summarizes all these contributions using the four dimensions provided by Porcu et al. (2012). 


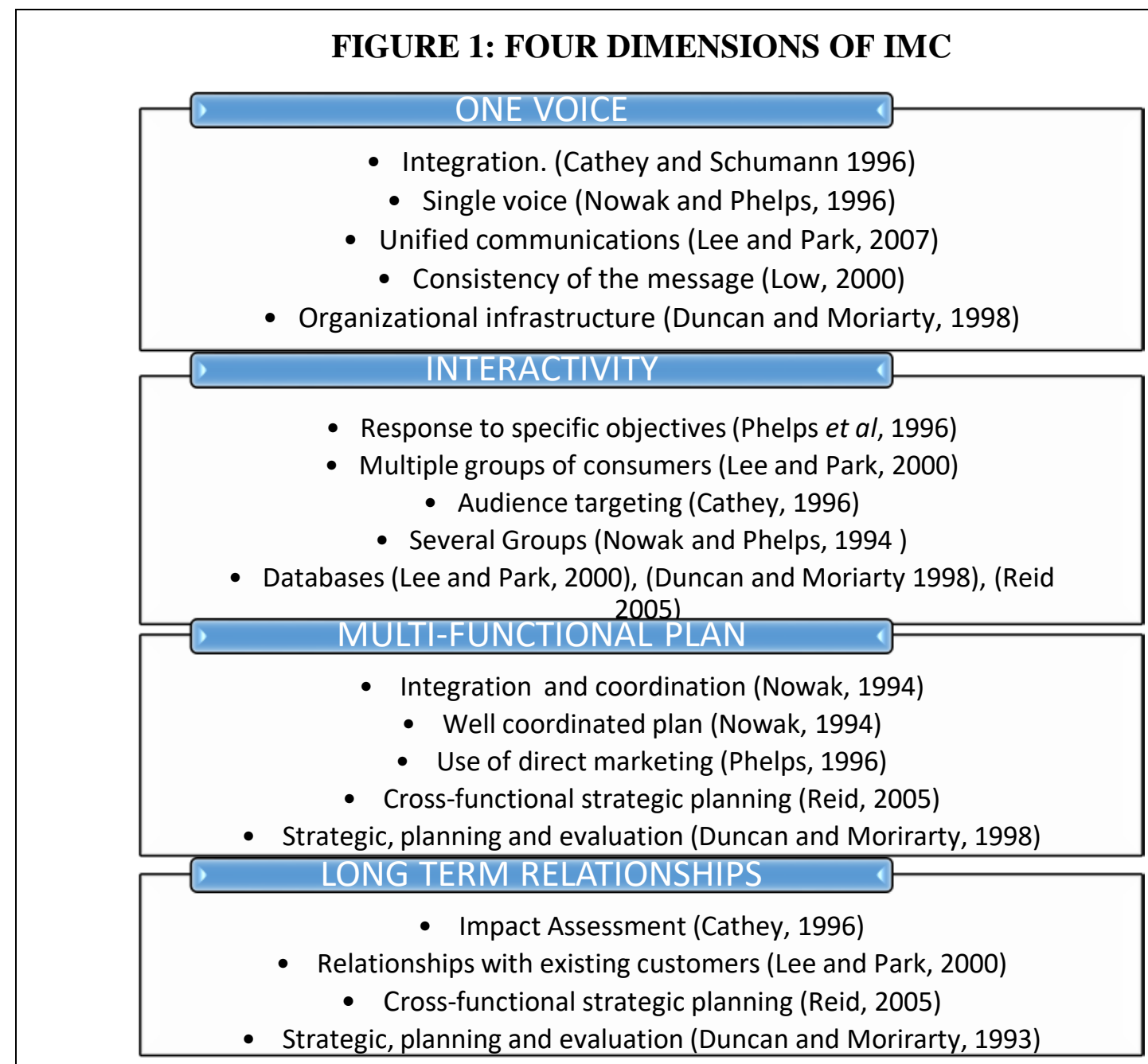

Source: Own elaboration.

\section{THE COCA-COLA INTEGRATED MARKETING COMMUNICATIONS MODEL}

The Coca-Cola Company is the world's largest beverage company. This company owns or licenses and markets more than 500 nonalcoholic beverage brands, primarily sparkling beverages but also a variety of still beverages such as waters, enhanced waters, juices and juice drinks, ready-to-drink teas, coffees, and energy and sports drinks. Coca-Cola is one of the most important brands and valued on the planet with a strong investment in marketing that already began in its infancy.

Coca-Cola company's marketing investment worldwide reached 5.8 billion dollars in 2018, representing 18.3 per cent of its sales, well above its direct rival PepsiCo, whose investment reached 6.5 per cent about the sales.

Between 2000 and 2018 the company made some important changes in its management leadership with Marcos de Quinto as the head of the marketing restructuring of the company, since he went from president of Coca-Cola Iberia to Executive Vice President \& Chief Marketing Officer (Worldwide). This manager is the architect of the changes in the company's marketing structure and the introduction of concepts such as IMC and Liquid and Linked. These are the main reasons for choosing this brand for our study. 
Focusing on the local market, Coca-Cola Spain is a service company to support franchised bottlers, nowadays merged in one enterprise Coca-Cola European Partners, therefore, most of the activities of the company focus on marketing. Coca-Cola Spain (service and Soft Drinks SL) is a subsidiary of The Coca-Cola Company for over half a century in Spain, with the headquarters in Madrid.

The Iberian Division, which brings together Spain and Portugal, is among the six largest in the world and generates, according to financial sources, 5 per cent of the profits of The CocaCola Company with sales of more than 2,600 million euros per year. Iberia Group is the seventh Coca-Cola company with the highest per capita consumption after Mexico, Chile, United States, Australia and Argentina, and the first one in the European Union.

We gathered relevant information on IMC at Coca-Cola Spain via a personal interview to Ismael Pascual, IMC Manager at Coca-Cola Spain.

A semi-structured questionnaire with 4 parts was used for the interview:

- $\quad$ first part focused on the marketing structure;

- $\quad$ second part on the strategy and methodology;

- $\quad$ third part on media tools used to implement the marketing strategy;

- four part on IMC dimensions.

\section{Marketing structure}

Figure 2 shows the organizational structure of the Coca-Cola company.

Mr. Marcos de Quinto was the President of Coca-Cola Iberia in charge of the structure and operations for over 14 years and the person responsible for the marketing implementation so the success of the company in Spain led Mr. de Quinto to the position of Executive Vice President and Chief Marketing Officer of The Coca-Cola Company in Atlanta on January 2015.

On the one hand, the President is in charge of different departments: Legal, Corporate Affairs and Finance, together with a support area called "Research in charge of marketing reports and metrics”. On the other hand, there is another main structure composed of a Country Manager or CEO, who assumes the responsibilities of marketing, sales and business and reports directly to the President.

Below the Country Manager or CEO, there are:

- Two marketing managers for different business units: soft drink, fruit juices and water.

- $\quad$ Two sales service units: national accounts and Franchise Operation (FO): Accounts for traditional food channels and atomized channels.

- A marketing area service called Integrated Marketing Communication, whose director is Mr. Pascual, IMC Manager at Coca-Cola Spain.

The IMC department has the following functional structure:

- $\quad$ Strategy and creativity: from the briefing to the creative idea.

- Connections: evolution of the classic media department, which integrates OESP (Owned, Earned, Shared, Paid) Media.

- Content, which is in charge of all the communication content.

- Digital, which reports to Content and Connections.

In practice, there are no separation lines and they work in multidisciplinary teams. four groups of four people each one sharing the same table, formed by a person of each area content, 
digital, connections, led by the person in charge of the strategy. Each group is responsible for a specific communication project.

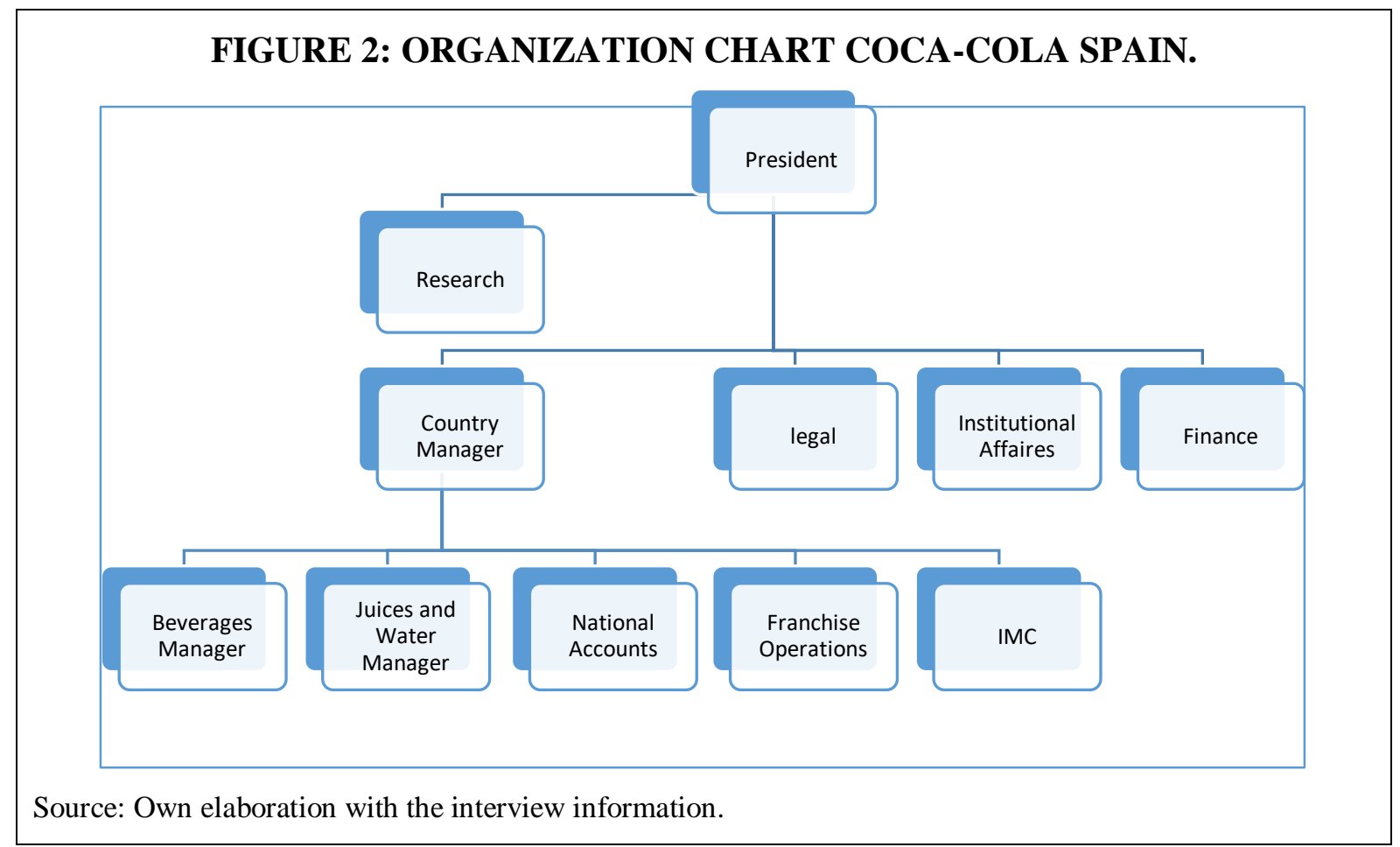

\section{Strategy and methodology}

In a second part of the interview, we focused on the methodology used in the company for Integrated Marketing Communications. We concluded the Director leads the marketing strategy and focuses on the Profit and Loss account of each of the brands. Subsequently, the project designs a briefing communication to the IMC department to develop and execute it. IMC manages all brand communication projects and some transversal projects. When working on a cross-communication project, brands are only tools and the goal has to be much more global. Transversal projects are decided in the Chief Committee and working within a business plan in this order: The strategy comes first, P \& L comes second, and at least the creative idea is developed. The strategy and P \& L report directly to the President of the company.

The company research is carried through the Research Department, which supported by specialized companies. In recent years, the department has focused on psychographic analysis of consumer rather than demographic profiles.

A new relationship with consumers and agencies that has developed Coca-Cola Global in the USA and that is an evolution from the "TV centric" (all centred on television) to a new model called "Liquid and Linked" where the ideas can flow between all the participants and linked, attached to the idea, the strategy and the business.

Once the briefing arrives to the IMC department, it starts developing the strategy and this leads to the creative idea, which is considered as important as the strategy itself. After the strategy and creative idea are approved by the Communications Committee formed by the IMC Manager, the President, the Country Manager, the two division Managers (beverages and water and juices) and Institutional Affairs Manager, the IMC team start working on the selection of media equipment connections focusing on impacts rather than on the concrete media. In parallel, the team develops the content, all supported by Digital. 
It is a multidisciplinary model rather than a linear model of equipment, as it can be observed in figure 3.

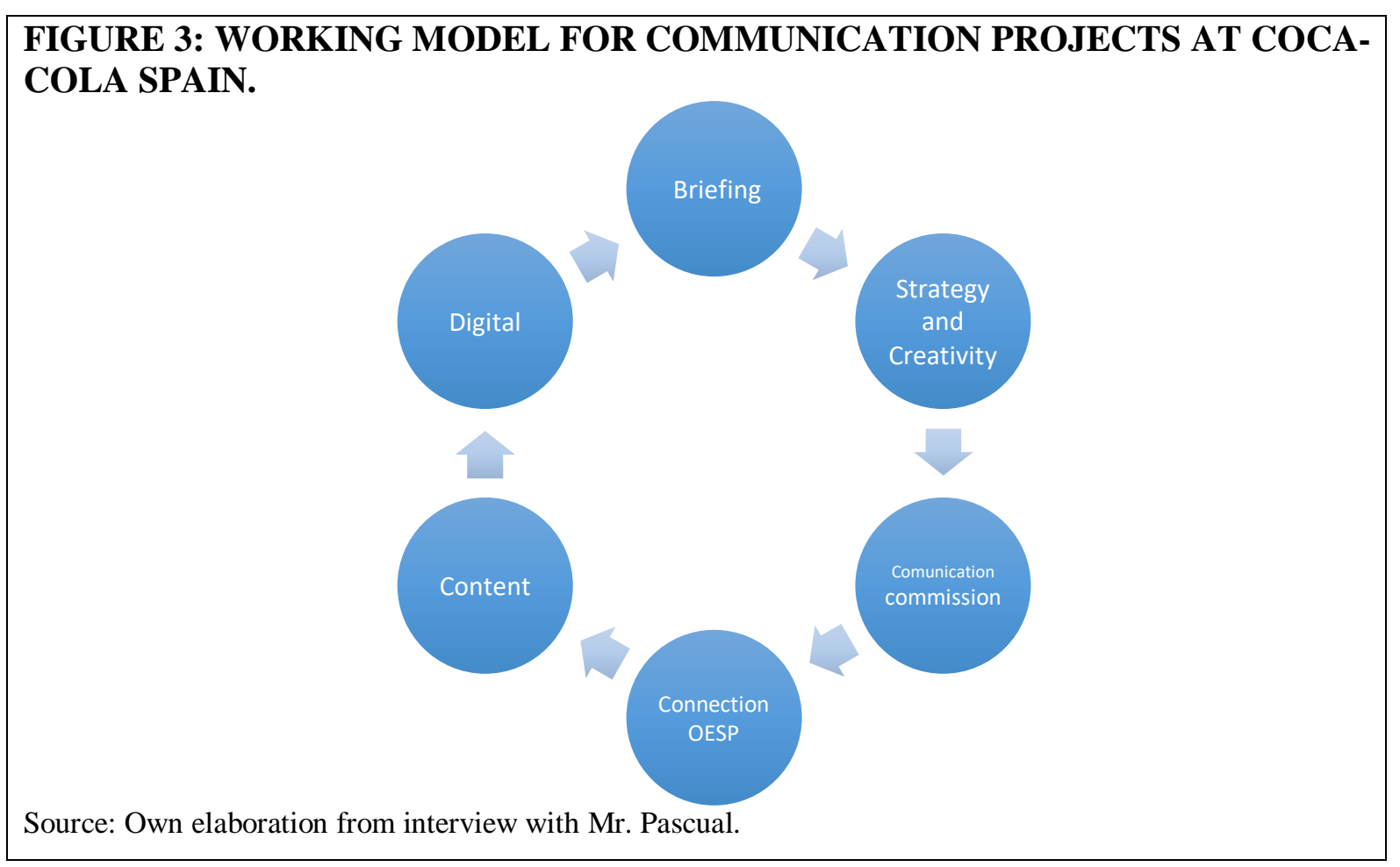

Media tools to implemented the marketing strategy

In Coca-Cola Spain, the structure and work modus operandi are unique, as well as their way of organizing communication tools. Aided by the company Carat, Coca-Cola has a new way of organizing the media tools, as detailed below:

- $\quad$ Owned: packaging, delivery trucks, digital windows, Twitter accounts, Facebook page, corporate website, among others.

- $\quad$ Earned: sending people to people, people who sees and shares basically the entire flow in social media.

- Shared with media companies, customers, employers. In this case, measure is more complex and sometimes considered as Owned or Earned media.

- Paid: conventional media, such as television commercials, radio, newspapers, magazines, cinema, outdoor advertising, Internet advertising.

How to measure investments in advertising has been modified and now estimate all impacts on the full dashboard, including sentiment data or positive and negative sentiment content. Consequently, they do not focus so much on GRPs, but actual impacts.

\section{CONCLUSIONS}

For many years, the structure of marketing in firms has not worked integrating different communications tools. Even universities have trained students in different areas without any consideration of integrated approaches. Parallel has developed a substantial change since the late 80 s to the present, where the strength of the Internet and new ways of communicating have changed radically. 
The first academics to talk about integration emerged in the Medill School of Journalism at Northwestern University in early 90s and from that moment on the development of research in IMC and its application in universities has been ongoing. Dozens of articles and research on the Integrated Marketing Communications endorse the concept, which has gained importance in today's academic world and its implementation has now become global.

The dimensions of IMC single voice, the integration and coordination of marketing communications proposed by Nowak and Phelps in 1994 have evolved towards a model in Coca-Cola, whose marketing department is called Integrated Marketing Communications.

After an in-depth interview with the IMC of Coca-Cola Iberia, three parts coinciding with the proposed IMC dimensions are analyzed: marketing structure, strategy and methodology, and the media tools used to implement the marketing strategy. The integration of the company reaches a model defined as Liquid and Linked, where all communication must be settled reaching all and of course be fully connected internally and with their publics. the structure of the department itself has gone from a hierarchical way to project management, where different teams of people led by a strategist work on the content and digital areas.

Transversal projects are decided in the Chief Committee, considering first the strategy, the P \& L and creative idea. With the support of Carat, the world's first media agency, CocaCola has developed a new media structure to be closer to the consumer and implement the communication strategy, organized in owned, earned, shared and paid media.

This new form of organization and work implemented by one of the most important companies in the world allows us to see how the CIM has changed the way marketing departments work and how they organize the means of contact with the consumer. A new way of understanding the marketing tools have been adopted by many firms. This new structure doesn't talk about the tool or way a consumer connects the brand, it is based on the way a company works with the tool, gathering in Owned, Earned, Shared and Paid.

Both marketers and academics can see in this example the development of how the way of communicating with consumers has changed and teaching marketing at the University should adapt these new times where everything is connected and there are hardly any barriers to information. Nowadays, consumers connect with brands in a wide range of ways and channels. Thus, marketing managers must be trained in how to integrate all the tools under a single strategy. New times require new ways of working, more dynamic structures and interdisciplinary work, all to integrate all marketing tools with business.

\section{BIBLIOGRAPHY}

ANFABRA. (2019). Hábitos de consumo de las bebidas refrescantes en España Asociación Nacional de Fabricantes de Bebidas Refrescantes (http://www.refrescantes.es/habitosde-consumo)

Cathey A, Schumann D. W. (1996): Integrated marketing communications: Construct development and foundation research. Conference of the American Academy of Advertising.

Caywood C, Ewing R. (1991): Integrated marketing communications: A new master's degree concept. Public Relations Review, vol. 17, $\mathrm{n}^{\circ}$ 3, pp.237-244.

Coca-Cola Company. (2000). Investors filings and reports https://investors.cocacolacompany.com

Coca-Cola España. (2019). Información corporativa.

https://www.cocacolaespana.es/conocenos/informacion-corporativa/estudios-impacto

Duncan T, Moriarty SE. (1998): A communication-based marketing model for managing relationships. The journal of marketing, $\mathrm{n}^{\circ}$ 62, pp.1-13. 
Duncan TR, Everett SE. (1993): Client perceptions of integrated marketing communications. Journal of Advertising Research, vol. 33, no 3, pp.30-39.

Interbrand. Best Global Brands (2000) https://interbrand.com/best-brands/

Kliatchko J. (2005) Towards a new definition of integrated marketing communications (IMC). International Journal of Advertising, vol. 24, $\mathrm{n}^{\mathrm{0}}$ 1, pp.7-34.

Kliatchko JG. (2008): Revisiting the IMC construct. International Journal of Advertising, vol. 27, $\mathrm{n}^{\mathrm{o}}$ 1, pp:133-160.

Kotler, Philip. (2000): Marketing management: The millennium edition. Prentice Hall international series in marketing. Prentice Hall. New Jersey.

Lee DH, Park CW. (2000): Conceptualization and measurement of multidimensionality of integrated marketing communications. Journal of Advertising Research.; vol. 47, $\mathrm{n}^{\circ}$ 3, pp.222-236.

Low GS. (2000) Correlates of integrated marketing communications. Journal of Advertising Research, vol. 40, n 3, pp.27-39.

Martínez Martínez IJ. (2006) Consecuencias de la estrategia integrada de comunicación. Razón y Palabra, $n^{\circ} 48$.

Madhavaram S, Badrinarayana V, McDonald RE. (2005). Integrated Marketing Communication (IMC) and Brand Identity as Critical Components of Brand Equity Strategy: A Conceptual Framework and Research Propositions,” Journal of Advertising, vol. 34, nº. 4, pp. 69-80.

Nowak G, Phelps J. (1994) Conceptualizing the integrated marketing communication's phenomenon: An examination of its impact on advertising and its implications for advertising research Journal of Current Issues and Research in Advertising, vol. 16, $\mathrm{n}^{\circ}$ 1, pp.49.

Pickton, D., Broderick, A., (2005). Integrated marketing communications. Pearson Education UK.

Phelps JE, Harris TE, Johnson E. (1996). Exploring decision-making approaches and responsibility for developing marketing communications strategy. Journal of Business Research, vol. 37, no 3, pp.217-223.

Porcu L., del Barrio-Garcia S., Kitchen P.J. (2012) How integrated marketing communications (IMC) works? A theoretical review and an analysis of its main drivers and effects. Comunicación y Sociedad, vol. 25, nº 1, pp. 313-348

Porcu L, del Barrio-Garcia S, Kitchen PJ. (2012). Measuring integrated marketing communication by taking a broad organisational approach. European Journal of Marketing, vol. 51, no 3, pp.692-718.

Reid, M. (2005) Performance auditing of integrated marketing communication (IMC) actions and outcomes. Journal of Advertising, vol. 34, $\mathrm{n}^{\circ}$ 4, pp.41-54.

Schultz DE, Kitchen PJ. (1997). Integrated marketing communications in US advertising agencies: An exploratory study. Journal of Business Research, vol. 37, n 5, pp.7-18.

Schultz DE, Kitchen PJ. (2000) A response to 'Theoretical concept or management fashion'. Journal of Business Research. 2000, vol. 40, n 5, pp.17-21

Schultz DE, Schultz HF. (2004). IMC the next generation: Five steps for delivering value and measuring returns using marketing communication. ed. McGraw Hill;

Šerić, M., Gil-Saura, I., Ozretić-Došen, D. (2015) Insights on integrated marketing communications: Implementation and impact in hotel companies. International Journal of Contemporary Hospitality Management, vol. 27, n 5, pp.958-979. 